УДК 625.03

Канд. техн. наук А.М. Штомпель

\title{
ЕКСПЛУАТАЦІЙНА ДОВГОВІЧНІСТЬ ЕЛЕМЕНТІВ ПРОМІЖНОГО ПРУЖНОГО СКРІПЛЕННЯ
}

\author{
Представив д-р техн. наук, професор А.А. Плугін
}

\begin{abstract}
Постановка проблеми в загальному вигляді. Безстикова колія на залізобетонних шпалах (БК) температурнонапруженого типу $\epsilon$ основною конструкцією верхньої будови на залізницях України. На сьогодні іiі протяжність складає понад $70 \%$ розгорнутої довжини головних колій [1].

Рейко-шпальна решітка (РШР) існуючої конструкції БК, що експлуатується на мережі залізниць, змонтована в основному 3 проміжним скріпленням типу КБ. Сучасна конструкція проміжного скріплення (безболтове 3 пружними клемами) застосована поки що на 3,3 тис. км, тобто на $11 \%$ розгорнутої довжини головних колій [1].

Масове укладання в колію залізобетонних шпал 3 проміжним скріпленням типу КБ розпочалося у 60-х роках минулого сторіччя й триває нині. Практичний досвід експлуатації цієї
\end{abstract}

конструкції проміжного скріплення підтвердив її відносно високу надійність і в той же час виявив такі іiі недоліки, як багатоелементність, значна металоємність, необхідність виконання робіт 3 періодичного (1-2 рази протягом року) змащування-підтягування клемних i закладних болтів. Саме це обумовлює підвищену капіталомісткість вузла проміжного скріплення типу КБ та додаткові експлуатаційні витрати на його поточне утримання.

Безболтове проміжне скріплення 3 пружними клемами (у тому числі й скріплення типу КПП, яке впроваджується на залізницях) вільне від перелічених вище недоліків. Тому технічна політика 3 удосконалення конструкції РШР передбачає розширення полігону укладання та експлуатації саме такої конструкції проміжного скріплення. 
У табл. 1 надано основні показники проміжного скріплення типу КБ та типу КПП.

Таблиця 1

\begin{tabular}{|l|c|c|}
\hline \multirow{2}{*}{ Показник } & \multicolumn{2}{c|}{ Тип скріплення } \\
\cline { 2 - 3 } & КБ-65 & КПП-5 \\
\hline Кількість елементів, шт./вузол & 21 & 7 \\
\hline Маса металевих елементів, кг/вузол & 11 & 4,7 \\
\hline Регулювання рейки у вертикальній площині, мм & 14 & - \\
\hline
\end{tabular}

Видно, що проміжне скріплення типу КПП містить утричі меншу кількість елементів у вузлі та має приблизно на $60 \%$ меншу металоємкість i, як наслідок, «виграє» за капіталомісткістю.

Окрім того, відсутність у конструкції скріплення типу КПП болтових з'єднань зменшує витрати, пов'язані 3 монтажем РШР та iii подальшою експлуатацією в колії. У роботі [2] визначено, що «застосування... скріплень... типу КПП порівняно зі... скріпленням типу КБ зменшує витрати на збирання рейкошпальної решітки приблизно на $48 \%$..., експлуатація верхньої будови колії 3 пружними скріпленнями типу КПП потребує менших витрат на утримання... приблизно на $25 \%$ \% .

Стратегія розвитку колійного господарства до 2015 року передбачає довести міжремонтний строк служби конструкції колії до 1500 млн т брутто [3] і впровадження проміжних скріплень 3 таким самим технічним ресурсом.

Тому потрібна оцінка працездатності (довговічності) скріплення типу КПП при напрацюванні тоннажу.

Як свідчить практичний досвід, «життєвий» строк РШР напряму залежить від терміну служби вузлів проміжного скріплення. У зв'язку з цим питання щодо оцінки працездатності проміжного скріплення (у цілому вузла й окремих його елементів) набуває певної актуальності в рамках системи технічного обслуговування конструкції ЗК.
Основні дослідження 3 даної проблеми. Скріплення типу КПП $\epsilon$ аналогом проміжного скріплення типу СБ3 , яке експлуатується на залізницях Польщі та Білорусі. Конструкція вузла скріплення типу СБ-3 (як й скріплення типу КПП) складається 3 двох анкерів, які замонолічуються у шпалу, двох пружних клем, полімерної прокладки, яка укладається на шпалу під підошву рейки, i двох електроізолюючих вкладишів, що встановлюються між пружною клемою та підошвою рейки. Працездатність скріплення типу СБ-3 у свій час була експериментально перевірена [4]. Результати цих натурних випробувань використовуються в даному дослідженні.

Мета даної статті полягає у визначені довговічності елементів проміжного пружного скріплення типу КПП.

Виклад основного матеріалу дослідження. Довговічність (технічний ресурс) будь-якого елемента РШР визначається обсягом напрацьованого тоннажу $\mathbf{T}_{\text {ел }}$ до моменту виходу його (елемента) з ладу, тобто до появи відмови у його роботі. $\mathrm{y}$ загальному вигляді величина параметра $\mathbf{T}_{\text {ел }}$ встановлюється через таку залежність:

$$
\mathbf{T}_{\text {ел }}=\int_{0}^{\infty} P(t) d t
$$

де $\boldsymbol{P}(\boldsymbol{t})=\boldsymbol{P}(\mathbf{T}>\boldsymbol{t})-$ імовірність безвідмовної роботи $\boldsymbol{i}$-го елемента вузла скріплення; 
$\boldsymbol{t}$ - час, протягом якого визначається ймовірність безвідмовної роботи $\boldsymbol{i}$-го елемента вузла скріплення;

T - напрацьований тоннаж до моменту появи відмови в роботі $\boldsymbol{i}$-го елемента вузла скріплення.

За наявності відповідних статистичних даних величина $\boldsymbol{P}(\boldsymbol{t})$ для $\boldsymbol{i}$-го елемента РШР визначається залежністю

$$
P(t)=\mathrm{N}(t) / \mathbf{N}_{3 \text { аг }},
$$

де $\mathbf{N}_{\text {заг }}$ - кількість елементів $\boldsymbol{i}$-го виду при $\mathbf{T}=0$;

$\mathbf{N}(t)$ - кількість елементів $\boldsymbol{i}$-го виду, що знаходяться в експлуатації (без відмови у їх роботі) на момент часу $\boldsymbol{t}$.

Вузол проміжного скріплення розглядається [5] як певна складна технічна система, елементи якої з'єднані послідовно. Імовірність безвідмовної роботи такої системи (у тому числі й конструкції проміжного скріплення типу КПП) встановлюється за формулою

$$
\boldsymbol{P}_{\text {скр }}=\boldsymbol{P}_{\text {анк }} \cdot \boldsymbol{P}_{\text {кл }} \cdot \boldsymbol{P}_{\text {прок }} \cdot \boldsymbol{P}_{\text {вкл, }}
$$

де $\boldsymbol{P}_{\text {анк}}, \boldsymbol{P}_{\text {кл }}, \boldsymbol{P}_{\text {прок}}, \boldsymbol{P}_{\text {вкл }}-$ імовірність безвідмовної роботи $\boldsymbol{i}$-го елемента вузла скріплення (анкера, клеми, прокладки, вкладиша).

При виконанні експериментальних досліджень [4] у якості оціночного критерію працездатності проміжного скріплення розглядався поодинокий вихід його елементів за дефектами. Встановлювалася емпірична залежність параметра $\boldsymbol{x}$, що досліджувався, від напрацьованого тоннажу $\mathbf{T}$ й на іiі основі оцінювалася працездатність $\boldsymbol{i}$-го елемента проміжного скріплення.

У табл. 2 наведено основні результати дослідження.

Таблиця 2

\begin{tabular}{|l|c|c|c|c|}
\hline \multirow{2}{*}{\multicolumn{1}{|c|}{ Показник (параметр $x$ ) }} & \multicolumn{3}{|c|}{ Значення показника для $i$-го елемента } \\
\cline { 2 - 5 } & $\begin{array}{c}\text { пружні } \\
\text { клеми }\end{array}$ & $\begin{array}{c}\text { полімерні } \\
\text { прокладки }\end{array}$ & $\begin{array}{c}\text { ізолюючі } \\
\text { вкладиші }\end{array}$ & $\begin{array}{c}\text { шпали } \\
\text { (анкери) }\end{array}$ \\
\hline $\begin{array}{l}\text { Поодинокий вихід елемента } \\
\text { ладу, \% загальної кількості } \\
\text { елементів, укладених при } \\
\text { Т=0 }\end{array}$ & $0,97 / 1,24$ & $33,6 / 74,4$ & $10,9 / 35,9$ & 5,30 \\
\hline $\begin{array}{l}\text { Тоннаж безвідмовної роботи, } \\
\text { елемента (Тел), млн т брутто }\end{array}$ & 713 & 25 & 1 & 1160 \\
\hline $\begin{array}{l}\text { Середній питомий вихід } \\
\text { елемента, \%/100 млн т } \\
\text { брутто }\end{array}$ & 0,12 / 0,11 & $4,2 / 6,6$ & $1,4 / 3,2$ & 0,24 \\
\hline $\begin{array}{l}\text { Середня питома } \\
\text { інтенсивність виходу } \\
\text { елемента, \%/100 млн т } \\
\text { брутто }\end{array}$ & $0,61 / 0,19$ & $4,3 / 6,8$ & $1,4 / 3,2$ & 0,40 \\
\hline
\end{tabular}

Примітка: Чисельник - при Т = 800 млн т брутто; знаменник - при Т = 1126 млн т брутто; у колонці «шпали» величини показників визначено при Т $=2184$ млн т брутто; параметр $\mathrm{T}_{\text {ел }}$ визначався при максимальному значенні $P(t)=1$.

Відповідна обробка наведених даних дозволила встановити математичні моделі, що характеризують вихід у дефектні (тобто появу відмови в роботі) елементів пружного скріплення типу КПП (як аналога скріплення типу СБ-3) у процесі експлуа- 
тації конструкції БК (див. табл. 3). При цьому у якості апроксимуючої функції застосовувалася лінійна залежність зміни параметра $\boldsymbol{x}$ від обсягу напрацьованого тоннажу.

Таблиця 3

\begin{tabular}{|c|c|}
\hline $\begin{array}{l}\text { Вихід у дефектні, \% загальної } \\
\text { кількості укладених (при Т=0) }\end{array}$ & $\begin{array}{c}\text { Функціональна залежність } x=f(\mathrm{~T}) \\
\text { та область її застосування }\end{array}$ \\
\hline анкери (шпали) & $x_{\text {анк }}=0,0024 \mathrm{~T} \quad(4) \quad / \mathrm{T}<2200$ млн т брутто/ \\
\hline пружні клеми & (5) / T < 1200 млн т брутто/ \\
\hline ізолюючі вкладиші & $\begin{array}{l}x_{\text {вкл }}=0,0136 \mathrm{~T} \quad(6) \quad / \mathrm{T}<800 \text { млН т брутто } / \\
x_{\text {вкл }}=10,9+0,0767(\mathrm{~T}-800) \quad(7) \\
/ \mathrm{T}=800-1200 \text { млн т брутто } /\end{array}$ \\
\hline полімерні прокладки & $\begin{array}{l}x_{\text {прок }}=0,042 \mathrm{~T} \quad(8) \quad / \mathrm{T}<800 \text { млН т брутто } / \\
x_{\text {прок }}=33,6+0,1252(\mathrm{~T}-800) \quad(9) \\
/ \text { T=800-1200 млн т брутто } /\end{array}$ \\
\hline
\end{tabular}

На основі встановлених залежностей $\boldsymbol{x}=\boldsymbol{f}(\mathrm{T})$ можна прогнозувати обсяг потреби в нових елементах скріплення типу КПП (для заміни дефектних) під час експлуатації конструкції БК на певних ділянках.

Однією з характеристик довговічності елементів конструкції РШР є ймовірність їх відмови $\boldsymbol{F}(\boldsymbol{t})$. Величина $\boldsymbol{F}(\boldsymbol{t})$ для $\boldsymbol{i}$-го елемента визначається формулою

$$
F(t)=\mathbf{r}(t) / \mathbf{N}_{3 \mathrm{ar}},
$$

де $\mathbf{r}(\boldsymbol{t})$ - кількість відмов елементів $\boldsymbol{i}$-го виду на момент часу $\boldsymbol{t}$ (тобто після напрацювання певного обсягу тоннажу T).

Використовуючи наведені вище залежності (див. табл. 3), у даному дослідженні встановлено значення показника $\boldsymbol{F ( t )}$ для окремих елементів і вузла в цілому скріплення типу КПП при напрацюванні певного тоннажу (див. табл. 4).

Таблиця 4

\begin{tabular}{|c|c|c|c|c|c|}
\hline \multirow{2}{*}{$\begin{array}{c}\text { Напрацьований тоннаж, } \\
\text { млн т брутто }\end{array}$} & \multicolumn{5}{|c|}{ Імовірність появи відмови у роботі $F(t)$} \\
\cline { 2 - 5 } & анкери & клеми & вкладиші & прозла \\
& в цілому \\
\hline 200 & 0,48 & 0,22 & 2,72 & 8,4 & 0,115 \\
\hline 400 & 0,96 & 0,44 & 5,44 & 16,8 & 0,224 \\
\hline 600 & 1,44 & 0,66 & 8,16 & 25,2 & 0,327 \\
\hline 800 & 1,92 & 0,88 & 10,90 & 33,6 & 0,425 \\
\hline 1000 & 2,40 & 1,10 & 26,24 & 58,6 & 0,706 \\
\hline 1200 & 2,88 & 1,32 & 41,58 & 83,7 & 0,909 \\
\hline
\end{tabular}

Обробка даних табл. 4 дозволила отримати функціональні залежності виду
$\boldsymbol{F}(\boldsymbol{t})=\boldsymbol{f}(\mathbf{T})$ для вузла проміжного скріплення типу КПП:

$$
\begin{gathered}
\boldsymbol{F}(\boldsymbol{t})=\mathbf{0 , 0 0 0 5 3} \mathbf{T} \text { (при Т }<800 \text { млн т брутто); } \\
\boldsymbol{F}(\boldsymbol{t})=\mathbf{0 , 4 2 4 8}+\mathbf{0 , 0 0 1 2}(\mathbf{T}-\mathbf{8 0 0})(\text { при T }=800 \div 1200 \text { млн т брутто). }
\end{gathered}
$$


Формули (11) - (12) можна застосовувати й для зворотної дії: при заданому рівні показника $\boldsymbol{F}(\boldsymbol{t})$ встановити прогнозну оцінку щодо довговічності (у напрацьованому тоннажі) вузлів проміжного скріплення типу КПП.

Висновки 3 даного дослідження i перспективи у даному напряму:

- встановлено математичні моделі виходу в дефектні елементів проміжного скріплення типу КПП при напрацюванні тоннажу;

- визначено функціональні залежності ймовірності появи відмови в роботі вузла скріплення типу КПП в процесі експлуатації;

- подальші дослідження стосуються оцінки довговічності конструкції рейкошпальної решітки в цілому.

\section{Список літератури}

1. Алейник, В.С. Будівництво та реконструкція залізничної мережі України для збільшення пропускної спроможності та запровадження швидкісного руху поїздів [Текст] / В.С. Алейник, В.В. Козак, М.Д. Костюк та ін. // Залізничний транспорт України. - 2010. № 5. - С. 3-12.

2. Костюк М.Д. Верхній будові колії - сучасні конструкції та технології [Текст] / М.Д. Костюк, Е.І. Даніленко, С.Д. Тараненко, Я.І. Микитін // Залізничний транспорт України. 2009. - № 3. - С. 36-38.

3. Горьканова, Т.Н. Инновационные направления развития путевого хозяйства [Текст] / Т.Н. Горьканова // Путь и путевое хозяйство. - 2010. - № 10. - С. 6-7.

4. Шварц, Ю.Ф. Результаты испытаний польских конструкций пути на Экспериментальном кольце ВНИИЖТа [Текст] / Ю.Ф. Шварц, В.В. Серебренников, Н.В. Рессина // Железные дороги мира. - 1996. - № 7. - С. 43-49.

5. Железнодрожный путь [Текст] / Т.Г. Яковлева, Н.И. Карпущенко, С.И. Клинов и др.; под ред. Т.Г. Яковлевой. - М.: Транспорт, 1999. - 405 с.

Ключові слова: безстикова колія; рейко-шпальна решітка; проміжне скріплення; відмова в роботі; вихід елементів за дефектами; напрацьований тоннаж.

\section{Анотаціï}

Розглядаються питання, які стосуються довговічності елементів проміжного пружного скріплення в процесі експлуатації.

Рассматриваются вопросы, касающиеся долговечности элементов промежуточного упругого скрепления в процессе эксплуатации.

Addresses issues related to durability of the elastic elements of the intermediate bond in service. 